\title{
KONDISI SOSIAL EKONOMI DAN KUALITAS HUNIAN RUMAH TANGGA NELAYAN DI DESA KUALA KECAMATAN SELAKAU KABUPATEN SAMBAS
}

\author{
Dian Equanti ${ }^{1}$, Galuh Bayuardi ${ }^{2}$ \\ ${ }^{1,2}$ Program Studi Pendidikan Geografi \\ Fakultas Ilmu Pendidikan dan Pengetahuan Sosial IKIP PGRI Pontianak \\ Jalan Ampera Nomor 88 Pontianak - 78116, Telepon (0561) 748219 Fax. (0561) 589855 \\ ${ }^{1}$ Alamat e-mail:dequanti@gmail.com
}

\begin{abstract}
Abstrak
Desa Kuala merupakan desa pesisir yang terletak di muara Sungai Selakau, dengan dominan aktivitas ekonomi nelayan tangkap tradisional, dan kegiatan ekonomi yang berkaitan. Jangkauan area tangkap nelayan tangkap yang sempit dan ketergangtungan yang besar pada kondisi alam menyebabkan penghasilan yang tidak menentu. Kondisi ini rentan terhadap pendapatan yang rendah dan hunian yang tidak layak. Untuk berkontribusi pada penyediaan data wilayah, penelitian ini bertujuan menggambarkan: satu, kondisi sosial ekonomi rumah tangga nelayan di Desa Kuala Kecamatan Selakau Kabupaten Sambas; dua, kualitas hunian rumah tangga nelayan di Desa Kuala Kecamatan Selakau Kabupaten Sambas. Hasil penelitian menunjukkan pertama, rendahnya pendapatan rumah tangga dengan komponen pengeluaran makanan lebih dari 50 persen dari total pendapatan, serta lebih dari 60 persen responden berpendidikan SD. Kedua, kualitas hunian masyarakat dalam kategori cukup, dengan 70 persen berdinding tembok, namun sebagian besar dengan air bersih dan sanitasi kurang layak.
\end{abstract}

Kata Kunci: nelayan, sosial ekonomi, kualitas hunian

\begin{abstract}
Kuala Village is located in coastal alluvial plan of Selakau River estuary, with dominant economic activities in traditional fishery and others related sector. For the traditional fishermen only access narrow catching area, and highly depend on nature dynamic, caused unpredictable income. This condition is susceptible to low income and improper housing. Contribute to provide regional data as development policy consideration, this research aimed to describe: first, social economic condition of fishermen households in Kuala Village of Selakau Sub-district, District of Sambas; second, housing quality owned by fishermen households in Kuala Village of Selakau Sub-district, District of Sambas. The result of this study shows the low income of household with more than 50 percent component of total income used for foods, and more than 60 percent of respondents reach Elementary School education. Second, quality of housing of owned by Selakau people was in moderate category, with 70 percent of houses using concrete wall, however most of them with improper clean water and sanitation.
\end{abstract}

Key words: fishermen, social economy, housing quality

\section{PENDAHULUAN}

Kelayakan rumah merupakan kebutuhan mendasar. Sebagai tempat berlindung, rumah harus memenuhi syarat fisik yaitu aman, serta mendukung kehidupan yang sehat bagi penghuninya. Undang-undang No. 1 Tahun 2011 
tentang Perumahan dan Kawasan Permukiman Pasal 1 ayat 7 menyatakan bahwa rumah adalah bangunan gedung yang berfungsi sebagai tempat tinggal yang layak huni, sarana pembinaan keluarga, cerminan harkat dan martabat penghuninya. Ini artinya secara mental rumah harus mampu memenuhi kenyamanan dan secara sosial dapat menjaga privasi setiap anggota keluarga, menjadi wahana tempat bimbingan serta pendidikan keluarga dilaksanakan. Rumah merupakan tempat pertama individu bertumbuh, belajar mengenal diri dan sekitar, ruang terkecil pembinaan karakter setiap orang, sebelum terjun ke masyarakat.

Hak untuk bertempat tinggal yang layak sebagai hak asasi manusia diatur dalam perundang-undangan yang ada, yaitu (1) Undang-Undang Dasar (UUD) 1945 dan pasal 28 H Amandemen ayat 1 tentang Perumahan dan Permukiman menyebutkan bahwa setiap orang berhak hidup sejahtera lahir dan batin, bertempat tinggal, dan mendapatkan lingkungan hidup baik dan sehat serta berhak memperoleh pelayanan kesehatan; (2) UU Nomor 39 Tahun 1999 tentang Hak Asasi Manusia Pasal 40 bahwa setiap orang berhak untuk bertempat tinggal serta berkehidupan yang layak; (3) Undang-Undang UU Nomor 11 Tahun 2005 tentang Kesepakatan Legal Formal/Kovenan Internasional tentang Hak-hak Ekonomi, Sosial dan Budaya (Covenant On Economic, Social and Cultural Rights) Pasal 11 bahwa negara pihak pada kovenan ini mengakui hak setiap orang atas standar kehidupan yang layak baginya dan keluarganya, termasuk pangan, sandang dan perumahan, dan atas perbaikan kondisi hidup terus menerus.

Daerah pesisir merupakan kawasan yang secara fisik dipengaruhi kondisi peralihan daratan dan perairan laut. Posisinya yang relatif rendah dengan ketinggian muka laut, membuat kawasan ini terkena dampak pasang surut air laut (Mustofa, dkk, 2008:356). Lingkungan permukiman pesisir ditandai dengan kawasan yang selalu tergenang air dan kesulitan akses air bersih. Kawasan pesisir ini menjadi tempat tinggal sebagian besar nelayan tradisional Indonesia. Lokasinya yang dekat dengan muara merupakan tempat perkembangbiakan nyamuk. Sejumlah faktor di atas menjadi alasan permukiman nelayan memiliki kualitas kurang baik. 
Nelayan tradisional Indonesia tergolong penduduk yang rentan terhadap kemiskinan. Rumah tangga nelayan memiliki ciri khusus seperti penggunaan wilayah pesisir dan laut (common property) sebagai faktor produksi, jam kerja mengikuti kondisi oseanografis (melaut rata-rata sekitar 20 hari dalam satu bulan, sisanya menganggur) (Wasak, 2012). Keterbatasan luas jangkauan area tangkap karena minimnya perlengkapan yang dimiliki, dan kondisi cuaca menyebabkan penghasilan yang tidak menentu. Kondisi ini menyebabkan investasi pada hunian yang layak juga kecil. Dengan asumsi bahwa lingkungan permukiman nelayan adalah daerah pesisir dekat dengan muara sungai, dan pendapatan nelayan yang rendah, menyebabkan hunian rumah tangga nelayan berkualitas rendah. Pemaparan asumsi kualitas hunian dan lingkungan permukiman daerah pesisir pada rumah tangga nelayan di atas tidaklah berlaku rata dalam distribusinya di seluruh permukaan bumi. Elemen-elemen penyusun karakteristik lingkungan maupun sosial akan mewarnai fenomena yang diamati, termasuk kualitas hunian dan lingkungan permukiman rumah tangga nelayan. Untuk mengamatinya diperlukan tahapan penelitian lapangan guna mengetahui kondisi nyata.

Tujuan penelitian ini adalah untuk mengetahui kondisi sosial ekonomi rumah tangga nelayan di Desa Kuala Kecamatan Selakau Kabupaten Sambas; dan mengetahui kualitas hunian rumah tangga nelayan di Desa Kuala Kecamatan Selakau Kabupaten Sambas. Manfaat penelitian sebagai laporan kondisi sosial ekonomi rumah tangga nelayan di Desa Kuala Kecamatan Selakau Kabupaten Sambas, serta menyediakan data kualitas hunian rumah tangga nelayan di Desa Selakau Kabupaten Sambas.

\section{METODE}

Penelitian yang dilakukan adalah penelitian deskriptif kuantitatif. Metode pengumpulan data dilakukan dengan cara survei terhadap masyarakat nelayan di Desa Kuala Kecamatan Selakau Kabupaten Sambas, Kalimantan Barat. Data yang diambil dalam penelitian ini dimaksudkan mengenali karakteristik populasi mencakup kondisi hunian, lingkungan permukiman dan sosial ekonomi 
masyarakat di Desa Kuala, maka diambil sejumlah responden sampel sebagai representasi.

Metode pengambilan sampel yang digunakan adalah kuota sampling. Wilayah sampel adalah Desa Kuala, yang terdiri dari lima satuan Rukun Tetangga (RT). Masing-masing RT diambil sejumlah 20 sampel rumah tangga, sehingga total sampel adalah 100. Dalam analisis datanya tidak bertujuan menggambarkan kondisi hunian dan kualitas permukiman di tingkat satuan area, namun mewakili kondisi Desa Kuala seluruhnya. Alat pengambilan data primer yang digunakan adalah kuesioner model tertutup. Dalam hal ini tim peneliti menyusun pilihanpilihan jawaban atas pertanyaan yang diajukan pada responden. Teknik pengumpulan data menggunakan wawancara langsung dengan responden, sambil mengisikan jawaban yang diberikan dalam kuesioner. Ini bertujuan menghindari kesalahan pengisian atau perbedaan pemahaman atas maksud dari pertanyaan survei. Analisis data dilakukan dengan tabulasi frekuensi persentase jawaban responden terhadap setiap item pertanyaan dalam kuesioner. Selanjutnya, dalam pembahasan, data-data persentase dideskripsikan, dilengkapi dengan data kualitatif yang diperoleh melalui observasi langsung untuk memperkuat pernyataan (Bayuardi, G., F, Andang., Superman,. 2017: 27).

\section{HASIL DAN PEMBAHASAN}

Kuesioner penelitian ini disebar ke rumah tangga yang terdapat di lima wilayah Rukun Tetangga (RT) di Desa Kuala Kecamatan Selakau. Jumlah kuesioner disebar sebanyak 205 eksemplar. Dari jumlah tersebut, kuesioner terjawab sebanyak 199 eksemplar atau mencapai 97 persen. Responden terdata 199 orang. 36,5 persen adalah kepala keluarga, hampir setengahnya (47,5 persen) adalah istri, dan 16 persen sisanya sebagai anak, orang tua dan lainnya. Dengan informasi hubungan responden dengan kepala keluarga yang menyatakan bahwa lebih dari 80 persen adalah kepala keluarga, atau isteri, diasumsikan bahwa sumber informasi kondisi sosial ekonomi rumah tangga berasal dari informan terdekat. Status migrasi responden menunjukkan sekitar 90 persen responden menjawab telah tinggal di Desa Kuala lebih dari 5 tahun. 
Rumah tangga nelayan memiliki keunikan dalam hal mata pencarian yang berhubungan dengan aktivitas ekonomi di sektor kelautan. Perikanan tangkap khususnya bagi masyarakat nelayan yang umumnya bermodal kecil, biasanya memiliki ketergantungan yang tinggi pada cuaca, persiapan sarana serta situasi yang dijumpai di laut. Faktor yang sulit dikendalikan sendiri oleh nelayan, seperti cuaca dan situasi di laut, membuat aktivitas menangkap ikan memiliki risiko tinggi sehingga perolehan ekonominya sulit diprediksi. Oleh karena itu, meskipun sebagian besar rumah tangga nelayan di wilayah Indonesia bertumpu pada pekerjaan menangkap ikan, di musim-musim cuaca tidak mendukung kapal-kapal kecil berlayar, rumah tangga nelayan akan beralih profesi ke aktivitas ekonomi daratan. Aktivitas ekonomi itu misalnya berdagang, atau berkebun.

Tabel 1 menunjukkan dominasi mata pencarian di bidang pertanian, yaitu petani dan nelayan sebesar 39,51 persen. Profesi terbesar kedua adalah karyawan swasta sebesar 15,43 persen. Dalam data ini muncul lebih dua puluh persen Kepala Keluarga dengan mata pencarian lainnya. Untuk jenis ini biasanya yang responden sebut dengan bahasa percakapan sebagai, "serabutan", "membantu tetangga dan menerima upah", "bangunan", dan sebagainya. Mata pencarian dalam kategori lainnya, maupun penyedia jasa biasanya masih berhubungan dengan aktivitas utama warga desa. Misalnya agen penjual solar, yang merupakan bahan bakar utama perahu nelayan. Ada pula jasa servis perahu (reparasi kapal nelayan), servis mesin kapal, pedagang yang menjual hasil tangkapan nelayan, rumah tangga yang mengolah hasil tangkapan sebagai ikan asin, dan sebagainya.

Tabel 1. Mata Pencarian Kepala Rumah Tangga

\begin{tabular}{|l|r|r|}
\hline \multicolumn{1}{|c|}{ Mata Pencarian Kepala Keluarga } & Persen (\%) & \multicolumn{1}{c|}{ Jumlah Terjawab } \\
\hline Pegawai Negeri Sipil & 3.09 & 5 \\
\hline Karyawan Swasta & 15.43 & 25 \\
\hline Petani atau Nelayan & 39.51 & 64 \\
\hline Pedagang & 9.88 & 16 \\
\hline Wirausaha & 8.02 & 13 \\
\hline
\end{tabular}




\begin{tabular}{|c|r|r|}
\hline Penyedia Jasa & 1.85 & 3 \\
\hline lainnya & 22.22 & 36 \\
\hline Jumlah & 100.00 & 162 \\
\hline
\end{tabular}

(Sumber : Data primer, 2016)

Pada data pendidikan ini, terlihat bahwa tingkat pendidikan responden masih rendah, dengan 81,56 persen hanya meraih ijazah hingga tingkat SMP. Lebih dari setengah responden atau 61,45 persen hanya menamatkan Sekolah Dasar. Rendahnya tingkat pendidikan ini berdampak pada jenis pekerjaan yang dapat diakses.

Tabel 2. Pendidikan Tertinggi Responden

\begin{tabular}{|l|r|r|}
\hline \multicolumn{1}{|c|}{ Tingkat Pendidikan } & \multicolumn{1}{c|}{ Jumlah Terjawab } & \multicolumn{1}{c|}{ Persen (\%) } \\
\hline SD & 110 & 61.45 \\
\hline SMP & 36 & 20.11 \\
\hline SMA & 26 & 14.53 \\
\hline $\begin{array}{l}\text { Perguruan Tinggi (Diploma, } \\
\text { Sarjana) }\end{array}$ & 7 & 3.91 \\
\hline \multicolumn{1}{|c|}{ Jumlah } & 179 & 100 \\
\hline
\end{tabular}

(Sumber: Data Primer, 2016)

Jumlah anggota rumah tangga yang dimaksud pada Tabel 3, menggunakan konsep yang dipakai BPS, yaitu penghuni rumah yang makan dari satu dapur yang sama. Pertama, data ini menjelaskan tentang konsep berbagi pendapatan dalam satu rumah tangga. Kedua, pada rumah tangga yang menumpukan sumber pendapatan pada Kepala Keluarga, maka jumlah anggota rumah tangga berkaitan dengan jumlah tanggungan yang harus dibiayai kebutuhan hidupnya sehari-hari.

Tabel 3. Jumlah Anggota Rumah Tangga (ART) yang Tinggal Satu Rumah

\begin{tabular}{|l|r|r|}
\hline \multicolumn{1}{|c|}{ ART Tinggal Serumah } & Persen (\%) & \multicolumn{1}{|c|}{ Jumlah Terjawab } \\
\hline $1-2$ orang & 12,99 & 23 \\
\hline $3-4$ orang & 44,07 & 78 \\
\hline $5-7$ orang & 31,64 & 56 \\
\hline Lebih dari 7 orang & 11,30 & 20 \\
\hline \multicolumn{1}{|c|}{ Jumlah } & 100 & 177 \\
\hline
\end{tabular}


Survei terhadap rumah tangga menunjukkan bahwa jumlah anggota rumah tangga di Desa Kuala Kecamatan Selakau ini sebagian besar adalah 3 - 4 orang (44 persen), dan $5-6$ orang (31,64 persen). Data yang diperoleh ini memperlihatkan persentase rumah tangga dengan jumlah anggota di atas 5 orang cukup besar, mencapai 42, 94 persen. Rumah tangga dengan jumlah ART hingga 4 orang sebesar 57,06 persen, yang di dalamnya termasuk keluarga kecil dengan 2 orang ART sebesar hampir 13 persen.

Tabel 4. Beban Tanggungan Kepala Keluarga

\begin{tabular}{|c|c|c|}
\hline Tanggungan KK & Persen $(\%)$ & Jumlah Terjawab \\
\hline $1-2$ orang & 31,82 & 56 \\
\hline $3-4$ orang & 51,14 & 90 \\
\hline 5 orang atau lebih & 17,05 & 30 \\
\hline Jumlah & 100,00 & 176 \\
\hline
\end{tabular}

Beban tanggungan KK dijelaskan sebagai jumlah ART yang berada di tanggung jawab KK dalam pembiayaan kebutuhan hidupnya (living cost). Berbeda dengan Dependency Ratio yang menggambarkan rasio ketergantunggan berdasarkan pertimbangan struktur umur penduduk, data jumlah tanggungan KK memberikan informasi ketergantungan riil secara ekonomi secara rerata dalam unit analisis rumah tangga. Beban tanggungan KK rumah tangga di Desa Kuala disajikan dalam Tabel 4.

Kepala Keluarga (KK) di Desa Kuala Kecamatan Selakau rata-rata memiliki jumlah tanggungan $3-4$ orang. Sementara rumah tangga dengan jumlah anggota sedikit akan menanggung $1-2$ orang. Terdapat 30 rumah tangga dengan tanggungan KK lebih dari 5 orang. Sebelum beranjak pada beban tanggungan, survei ini meliput jumlah ART yang memiliki penghasilan. Data yang diperoleh seperti Tabel 5.

Tabel 5. Jumlah ART yang Bekerja

\begin{tabular}{|l|r|r|}
\hline \multicolumn{1}{|c|}{ ART bekerja } & Persen (\%) & Jumlah Terjawab \\
\hline Hanya KK (1 orang) & 50,56 & 91 \\
\hline
\end{tabular}




\begin{tabular}{|c|r|r|}
\hline 2 orang & 41,11 & 74 \\
\hline 3 orang atau lebih & 8,33 & 15 \\
\hline Jumlah & 100,00 & 180 \\
\hline
\end{tabular}

Pekerjaan menangkap ikan adalah pekerjaan yang penuh risiko, sehingga pekerjaan ini umumnya dikerjakan lelaki. Dalam hal ini dipahami bahwa kepala keluarga nelayan akan bekerja penuh, dan tidak dapat dibantu anggota keluarga yang lain. Ketergantungan pada satu sumber pencari nafkah ini menyebabkan rumah tangga nelayan identik dengan kemiskinan. Tabel 5 menunjukkan ketergantungan yang sangat tinggi dari sebagian besar rumah tangga di Desa Kuala pada penghasilan KK. Kondisi ini memicu kerentanan ekonomi, terlebih dilihat pada jenis mata pencarian yang digeluti juga memiliki fluktuasi penghasilan yang sangat tinggi, yaitu petani dan nelayan. Rumah tangga yang ditopang oleh 2 orang yang bekerja sebanyak 49,44 persen.

Jumlah tanggungan ini bergantung pada jumlah anggota rumah tangga yang sudah bekerja dan memiliki penghasilan. Dalam rumah tangga, khususnya di Indonesia, anak punya kecenderungan bergantung pada orang tuanya hingga dewasa. Seringkali hingga telah menikah pun, orang tua tidak masih merasa perlu membantu perekonomian keluarga baru anaknya tersebut. Budaya ini menyebabkan KK memiliki beban yang sangat besar. Beban tanggungan juga selaras dengan komposisi ART yang berusia anak dan lansia.

Tidak dimungkiri di negara berkembang, jumlah jam kerja yang panjang tidak diiringi dengan pendapatan yang meningkat. Oleh karenanya, satu jenis pekerjaan tidak cukup untuk memenuhi kebutuhan satu keluarga. Tidak hanya di perkotaan, di pedesaan masyarakatnya juga memilih untuk menekuni lebih dari satu jenis pekerjaan agar mendapat penghasilan yang lebih baik. Berikut data pekerjaan sampingan yang ditekuni KK di Desa Kuala, Kecamatan Selakau.

Tabel 6. Pekerjaan Sampingan Kepala Keluarga

\begin{tabular}{|c|c|c|}
\hline Pekerjaan Sampingan & $\begin{array}{c}\text { Persen } \\
(\%)\end{array}$ & $\begin{array}{c}\text { Jumlah } \\
\text { Terjawab }\end{array}$ \\
\hline Petani & 23,53 & 24 \\
\hline
\end{tabular}




\begin{tabular}{|l|r|r|}
\hline Pedagang & 18,63 & 19 \\
\hline Wirausaha & 26,47 & 27 \\
\hline Penyedia Jasa & 2,94 & 3 \\
\hline Lainnya Jumlah & 28,43 & 29 \\
\hline \multicolumn{2}{|c|}{ Jur } & 102 \\
\hline
\end{tabular}

Data ini menunjukkan pekerjaan sampingan yang ditekuni sebagian besar adalah perdagangan, dan bidang usaha lain. Persentase mereka yang menekuni usaha dagang maupun wirausaha menjadi optimisme bagi kemandirian ekonomi warga. Terdapat 45 persen rumah tangga yang bergerak di bidang perdagangan maupun wirausaha. Saat pengamatan langsung, kegiatan wirausaha dan perdagangan terutama berkaitan dengan hasil perikanan, misalnya berjualan ikan hasil tangkapan nelayan, mengolah ikan menjadi ikan asin dan kerupuk.

Rerata penghasilan yang diperoleh dari pekerjaan utama disajikan Tabel 7. Dari Tabel 7, secara garis besar, kita dapat menggolongkan penghasilan yang diperoleh dari pekerjaan utama KK ke dalam 3 kelompok pendapatan; yaitu rendah, sedang, dan tinggi. Nilai penghasilan di kelompok paling rendah yaitu kurang dari 1 juta rupiah, diperoleh 18,29 persen responden. Untuk penghasilan menengah, ada dua golongan, yaitu menengah bawah, dan menengah atas. Penamaan menengah bawah dan atas ini mengacu pada penggolongan untuk kelompok sampel penelitian. Tentu batas klasifikasi ini tidak dapat digeneralisasi di luar populasi penelitian selain Desa Kuala, Kecamatan Selakau. Pendapatan golongan menengah bawah, dengan nilai 1 sampai 2,5 juta rupiah diperoleh setengah responden atau 53,66 persen. Pendapatan golongan menengah atas, dengan nilai sekitar 2,6 hingga 3,5 juta rupiah diperoleh 20,12 persen responden. Sisanya adalah KK dengan pendapatan tertinggi dari pekerjaan utama, senilai 3,6 juta rupiah atau lebih, yang diperoleh 7,93 persen responden.

Tabel 7. Penghasilan Kepala Keluarga dari Pekerjaan Utama

\begin{tabular}{|c|c|c|}
\hline $\begin{array}{l}\text { Penghasilan } \\
\text { (per bulan) }\end{array}$ & $\begin{array}{c}\text { Persen } \\
(\%)\end{array}$ & Jumlah Terjawab \\
\hline$<$ Rp1 juta & 18,29 & 30 \\
\hline Rp1 juta - Rp2,5 juta & 53,66 & 88 \\
\hline
\end{tabular}




\begin{tabular}{|c|r|r|}
\hline Rp2.6 juta - Rp3,5 juta & 20,12 & 33 \\
\hline Rp3,6 juta atau lebih & 7,93 & 13 \\
\hline Jumlah & 100,00 & 164 \\
\hline
\end{tabular}

Pekerjaan sampingan tampaknya hanya menghasilkan pendapatan yang relatif kecil jumlahnya. Separuh KK memperoleh penghasilan kurang dari satu juta rupiah per bulan dari pekerjaan sampingan. Meskipun ada juga KK yang memperoleh penghasilan dari pekerjaan sampingan di atas 2,6 juta rupiah per bulan, persentasenya cukup kecil, kurang dari 10 persen.

Komponen pengeluaran digunakan untuk mengetahui kondisi perekonomian masyarakat. Semakin tinggi pengeluaran, mencerminkan daya beli masyarakat yang tinggi. Di negara-negara berkembang, dengan pendapatan per kapita yang rendah, menyebabkan hampir seluruh pendapatan yang dihasilkan digunakan untuk membiayai kebutuhan hidup. Akibatnya pada masyarakat berpendapatan rendah, hampir tidak tersisa pendapatan yang dialokasikan untuk tabungan (saving) dan investasi. Dari sinilah konsep pengeluaran dianggap dapat menggantikan pendapatan pada masyarakat berpendapatan rendah.

Pengelompokan pengeluaran secara umum dibagi menjadi dua, yaitu pengeluaran makanan dan nonmakanan. Semakin tinggi proporsi pengeluaran untuk makanan, semakin rendah tingkat kesejahteraan ekonominya. Pengeluaran untuk makanan penduduk di Desa Kuala tampak pada Tabel 8.

Tabel 8. Rerata Pengeluaran untuk Makanan

\begin{tabular}{|c|r|r|}
\hline \multicolumn{1}{|c|}{ Pengeluaran Makanan per bulan } & Persen (\%) & Jumlah Terjawab \\
\hline Kurang dari Rp600.000 & 23,46 & 38 \\
\hline Rp600.000 - Rp1000.000 & 50 & 81 \\
\hline Lebih dari Rp1000.000 & 26,54 & 43 \\
\hline Jumlah & 100,00 & 162 \\
\hline
\end{tabular}

Bahasan mengenai aset yang berkaitan dengan kesejahteraan, di antaranya ditunjukkan oleh status kepemilikan hunian. Status kepemilikan hunian 
berimplikasi pada perbedaan beban ekonomi yang ditanggung oleh mereka yang tinggal di rumah berstatus sewa, rumah hak milik, atau menumpang pada keluarga besar. Warga yang tinggal di rumah hak milik lebih bebas mengatur ekonomi rumah tangganya sendiri. Pada keluarga yang tinggal menumpang pada keluarga besar, biasanya memiliki tanggungjawab sosial untuk berbagi, atau turut urun partisipasi dalam pembiayaan rumah tangga, meskipun nilainya tidak lebih besar dibanding hidup mandiri. Mereka yang tinggal di rumah berstatus sewa, memiliki pengeluaran rutin agar diperbolehkan tetap tinggal di hunian saat ini, disamping biaya hidup lain.

Sejumlah penelitian tentang sosial sosial ekonomi rumah tangga nelayan di desa pesisir Sulawesi Utara, menunjukkan bahwa rumah tangga nelayan yang pendapatannya semata-mata bergantung pada usaha penangkapan ikan hanya mampu memenuhi kebutuhan hidup sehari-hari, dan jika ada yang tersisa digunakan untuk biaya sekolah anak, membeli pakaian dan memperbaiki tempat tinggal (Mantjoro, 1988 dalam Wasak, 2012:1330).

Survei status kepemilikan hunian di Desa Kuala, menunjukkan sebagian besar (80 persen) responden memiliki sendiri hunian yang mereka tempati. Terdapat 17,6 persen responden yang tinggal bersama keluarga besar, dan sangat jarang dijumpai rumah tangga berstatus tinggal di rumah kontrak. Komponen kualitas hunian turut mempertimbangkan luas hunian, karena rumah perlu mengakomodasi aktivitas dan kenyamanan penghuni. Kebutuhan per orang untuk melakukan aktivitas dasar, meliputi tidur, makan, kerja, duduk, dan ruang gerak lainnya menurut UU No. 1 Tahun 2011 tentang Perumahan dan Kawasan Permukiman, adalah 7,2 - 12 meter per segi per orang. Jika penghuni rumah 4 orang anggota rumah tangga, artinya luas ideal sekitar $30 \mathrm{~m}^{2}$, atau seturut luas standar rumah tapak adalah tipe 36.

Hasil survei menunjukkan luas rumah responden relatif sempit, dengan sebagian besar luas lantai kurang dari 25 meter persegi. Responden dengan jawaban ini mencapai 88,74 persen. Sisanya adalah rumah tangga yang memiliki luas lantai hunian lebih dari 25 meter persegi. Data luas lantai yang kemudian dibandingkan dengan rata-rata jumlah anggota rumah tangga yang tinggal 
serumah, menghasilkan analisis mengenai kelayakan luas hunian. Data demografi sebelumnya menunjukkan jumlah anggota rumah tangga rata-rata adalah 3-4 orang. Jumlah ini masih bisa diakomodir oleh rumah tipe 21 hingga 36. Namun ada juga rumah tangga yang dihuni 5 hingga 7 orang penghuni dalam 1 rumah. Jumlah rumah tangga seperti ini cukup besar, hingga 42,9 persen responden. Jika dengan luas minimal kebutuhan rata-rata 7,2 meter per segi per orang, luas minimal yang dibutuhkan adalah 35 meter per segi, maka hanya ada kurang dari 10 persen rumah dengan luas yang layak.

Kondisi fisik hunian yang mempengaruhi kualitas rumah adalah dinding, lantai, dan atap. Pengisian oleh enumerator dalam survei ini memasukkan data dinding, lantai maupun atap adalah bahan bangunan dominan. Hunian yang dibangun secara permanen menggunakan bahan yang lebih tahan lama dan awet, akan berpengaruh terhadap kondisi penghuninya. Secara umum, dinding dari plester semen atau beton dianggap lebih baik daripada papan, karena kemampuannya bertahan menahan kelembaban, dibanding papan kayu.

Bahan bangunan untuk dinding yang digunakan oleh rumah tangga responden ada dua macam, yaitu papan dan tembok. Hasil survei ini menunjukkan dinding rumah responden sudah menggunakan tembok, sebanyak 70,32 persen, sisanya 29,68 persen masih menggunakan papan. Tampaknya masyarakat di Desa Kuala ini secara ekonomi mampu membiayai pembangunan rumah mereka untuk dibangun permanen.

Berbeda dengan dinding yang dibangun permanen dengan tembok semen, lantai masih didominasi oleh papan, hingga oleh 86,45 persen responden. Papan yang banyak digunakan sebagai bahan bangunan adalah kayu ulin. Kayu ini bersifat kuat, tahan dalam terhadap cuaca dan tidak mudah lapuk di lahan yang selalu terendam air. Meskipun demikian, penggunaan kayu cenderung membuat ruangan lembab. Tiang-tiang rumah dibangun di atas tanah yang selalu terendam karena ketinggian daratan yang hanya $0-4$ meter mdpl, sehingga dari lantai yang dibuat dari kayu kelembaban tanah akan terasa di lantai. Untuk itu penghuni rumah perlu menjaga agar rumahnya selalu kering. Bagian yang biasanya selalu basah, adalah dapur dan area mencuci di belakang rumah. 
Air bersih merupakan kebutuhan vital. Kualitas air, baik itu air yang digunakan untuk mencuci atau dikonsumsi akan berpengaruh pada kesehatan masyarakatnya. Pada umumnya, masyarakat akan menggantungkan hidupnya dari sumber air yang dijumpai di sekitar mereka. Oleh karena Desa Kuala dilintasi Sungai Selakau yang cukup lebar, air sungainya dimanfaatkan penduduk setempat terutama untuk kebutuhan mandi dan mencuci. Air sungai dialirkan melalui selang-selang air yang panjang ke penampungan air di rumah-rumah, didorong menggunakan mesin penyedot air. Mereka yang memanfaatkan air sungai untuk MCK sebanyak 94 persen. Sisanya mendapat sambungan pipa ledeng dari PDAM.

Sebagaimana pada umumnya daerah di Kalimantan Barat, air PDAM berasal dari air baku air sungai yang mengalami proses disinfektan dan penjernihan, sehingga tidak layak dijadikan air baku minum. Oleh sebab itu umumnya, penduduk di Kalimantan Barat memanfaatkan air hujan sebagai sumber air minum. Air hujan bersifat asam, dan minim kandungan mineral. Ini menyebabkan masyarakat rentan mengalami sakit maag dan gigi keropos.

Kondisi sanitasi sangat penting bagi kesehatan penghuni rumah. Komponen sanitasi dalam survei ini meliputi tempat buang air besar (BAB) dan saluran pembuangan air limbah. Perilaku berkaitan dengan kebersihan lingkungan yang didata adalah cara penanganan sampah.

Hasil survei ini masih memperlihatkan bahwa masih perilaku BAB yang tidak higienis masih dilakukan oleh masyarakat di Desa Kuala. Terdapat 15,69 persen responden atau 24 orang responden yang menjawab melakukan BABS (buang air besar di sungai). Hal ini dapat menyebabkan air sungai yang dipakai masyarakat untuk membersihkan pakaian, mandi dan mencuci perkakas dapur tercemar bakteri e-coli dari feces manusia. Data selanjutnya cukup memberi optimisme pada perilaku sadar sanitasi adalah 84,32 persen rumah tangga responden sudah memiliki WC di dalam rumah. Sekitar 24,84 persen di antaranya tidak memiliki septic tank. Kondisi ini akan mencemari tanah atau lingkungan sekitar rumah. Pernah juga dijumpai, penyebutan WC tanpa septic tank yang dimaksud penduduk sebenarnya adalah kotoran akan langsung jatuh di badan air, meskipun jamban berada di rumah. Perilaku ini sama berisiko dengan BABS 
dalam hal paparan bakteri e-coli penyebab diare. Kondisi ini tidak memenuhi syarat jamban sehat. Dalam Pedoman Teknis Penilaian Rumah Sehat; Depkes RI 2007 disebutkan syarat jamban yang baik antara lain sebagai berikut: tanah permukaan tidak boleh terkontaminasi;tidak boleh terjadi kontaminasi pada air tanah yang mungkin memasuki mata air atau sumur; tidak boleh terkontaminasi air permukaan; tinja tidak boleh terjangkau oleh lalat dan hewan lain; jamban harus bebas dari bau atau kondisi yang tidak sedap dipandang; metode pembuatan dan pengoperasian harus sederhana dan tidak mahal. Cemaran yang berasal dari limbah domestik tidak hanya berupa sampah padat yang masuk ke lingkungan. Perilaku BAB dan saluran buangan limbah akan menjadi sumber polutan yang dapat menyebarkan penyakit.

\section{SIMPULAN}

Desa Kuala merupakan desa pesisir yang terletak di muara Sungai Selakau, dengan dominan aktivitas ekonomi nelayan tangkap, dan kegiatan ekonomi yang berkaitan. Median pendapatan kepala keluarga (KK) dari pekerjaan utama sekitar 1 sampai 2,5 juta rupiah per bulan. Penghasilan ini digunakan untuk membiayai anggota rumah tangga yang menjadi tanggungan 2 - 5 orang. Ketidakpastian penghasilan dari kegiatan nelayan tangkap yang bergantung cuaca, membuat hampir semua KK memiliki pekerjaan kedua (sampingan), yang menghasilkan data median penghasilan kurang dari 1 juta rupiah.

Kualitas hunian masyarakat di Desa Kuala cukup baik, dari aspek kelayakan luas kebutuhan minimal per orang, jenis dinding dan lantai. Masih dijumpai masyarakat Desa Kuala yang tidak memiliki sarana sanitasi yang layak dan melakukan perilaku Buang Air Besar di Sungai (BABS). Kebiasaan ini dapat mencemari badan air, khususnya sungai yang dipakai sehari-hari.

Rendahnya pendapatan masyarakat nelayan berimplikasi pada rendahnya daya beli untuk kebutuhan sekunder dan tersier. Pembinaan di bidang peningkatan perekonomian dapat diupayakan melalui diversifikasi sumber pendapatan, khususnya yang bergerak di bidang pengolahan hasil tangkapan nelayan. 
Kebiasaan BABS berimplikasi pada potensi pencemaran badan air di lingkungan sekitar. Untuk itu disarankan adanya sosialisasi dan pemberdayaan masyarakat bagi penyediaan sarana sanitasi dan MCK komunal terstandar.

\section{DAFTAR PUSTAKA}

Bayuardi,Galuh., Firmansyah, Andang., \& Superman. 2017. Javanese Migrans' World View. International Conference The Asia Bringing Time, Space \& Socio-Economic Life Together. Semarang: Fakultas Ilmu Sosial UNNES.

Departemen Kesehatan RI. Pedoman Teknis Penilaian Rumah Sehat. Direktorat Jenderal Pengendalian Penyakit dan Penyehatan Masyarakat Tahun 2007.

Undang-Undang RI No. 11 Tahun 2005 tentang Pengesahan International Covenant On Economic, Social and Cultural Rights /Ecosoc (Kesepakatan Legal Formal/Kovenan Internasional tentang Hak-hak Ekonomi, Sosial dan Budaya).

Kusnoputranto, Haryoto. 1983. Aspek Kesehatan Masyarakat dari Pemukiman di Wilayah Perkotaan. Disajikan pada Seminar Habitat Nasional I, Ikatan Arsitek Indonesia, di Jakarta 24-26 Maret 1983.

Mustofa, Bisri dan Sektiyawan, Inung. 2008. Kamus Lengkap Geografi. Yogyakarta: Panji Pustaka.

Supraptini, 2005. Gambaran Rumah Sehat Di Indonesia, Berdasarkan Analisis Data Susenas 2001 dan 2004. Puslitbang Ekologi dan Status Kesehatan Badan Litbangkes.

Yusuf, Alfan Akbar. 2005. Kajian Kualitas Lingkungan Permukiman Kota di Kelurahan Kiduldalem dan Kelurahan Bandulan Kota Malang. Tesis. Yogyakarta: Sekolah Pascasarjana UGM.

Wasak, M. (2012). Keadaan Sosial Ekonomi Masyarakat Nelayan di Desa Kinabuhutan Kecamatan Likupang Barat, Kabupaten Minahasa Utara, Sulawesi Utara. Pasipic Journal , 1339-1342. 